\title{
Peter Senge puolustaa luontoa ja luonnollista oppimista
}

\author{
Peter Senge on eniten siteerattuja kirjoittajia, kun \\ puhutaan oppivista organisaatioista. Hänen tunnetuin \\ kirjansa The Fifth Discipline ${ }^{1}$ ilmestyi Yhdysvalloissa \\ vuonna 1990 ja sai miltei kulttikirjan maineen. Sengeä \\ pidetään ihmisenä, joka tietää hyvin paljon oppivan \\ organisaation kysymyksistä, hän on jotakin tällä alueella. \\ Ennakkokuva vahvasta osaajasta oli vankkumaton \\ lupautuessani haastattelemaan Sengeä.
}

Tapaaminen muutti ennakkokäsityksiäni ja -odotuksiani.

\begin{abstract}
"Oliko koko teollinen aikakausi - samalla kun se tavoitteli tehokkuutta - luonnonvastaisuudessaan kupla, missä luonto on pelkkä luonnonvara ja ihminen pelkkä inhimillinen resurssi?”, Senge huomauttaa ja jatkaa: "Jos voimme rakentaa oppivia organisaatioita, miksi siis emme pystyisi rakentamaan sellaista talousjärjestelmää, joka ei riko luonnonlakeja vastaan. Eihän insinöörikään suunnittele siltaa ottamatta huomioon luonnonlakeja, siis painovoimalakeja. Me voimme rakentaa parempia yrityksiä ja parempia kouluja, joissa luonto, luonnollisuus ja luonnon lainalaisuudet otetaan huomioon."
\end{abstract}

Haastattelu, samoin kuin Peter Sengen esitys Jyväskylässä ${ }^{2}$ marraskuussa, nostivat siis Sengestä esiin yllättävän puolen: hänen sydäntään lähellä ovat olleet jo kauan kaikki sekä fyysiseen että sosiaaliseen ympäristöön liittyvät asiat.

"The Fifth Discipline -kirja ei sijoittunut urani alkuvaiheisiin, vaan viisitoista vuotta sen jälkeen. Kaikki alkuperäiset kiinnostukseni kohteet liittyivät ympäristöön. Tämän kautta tulin kiinnostuneeksi myös systeemiajattelusta. Akateeminen urani liittyi kokonaan juuri monimutkaisten, ei- säännönmukaisten systeemien ymmärtämiseen”, luonnehti Peter Senge omaa kehitystään.

\section{Muutoksen julistaja törmäsi muutoshitauteen}

Senge sanoi olevansa uransa alkuvaiheissa enemmänkin toteuttaja kuin asioiden teoreettinen pohdiskelija. Tämä johti hänet muutoksen ja oppimisen maailmaan:

"Olin enemmän kiinnostunut asioiden muuttamisesta käytännössä kuin teorioiden kehittelystä. Suurten organisaatioiden muutosprosessit opettivat minulle paljon siitä, kuinka laajat sosiaaliset järjestelmät voivat muuttua", hän kuvasi omaa suuntautumistaan.

Muutosten läpivienti oli työlästä, ja itse asiassa Senge kommentoikin asiaa siten, että yritykset eivät olleet vielä kypsiä ottamaan ihmisiä tai ympäristöä huomioon liiketoiminnassaan.

"Täytyy olla kärsivällinen ja täytyy odottaa, tämä kaikki on vienyt jo kohta kolmekymmentä vuotta. Oli päivän selvää, että yrityksissä ei ollut todellista kiinnostusta, näitä asioita ei nähty stra- 
tegisina kysymyksinä”, hän totesi.

Vaikka Peter Senge aloitti työnsä ympäristöasioiden hyväksi jo vuosikymmeniä sitten, hän on silti uskonut koko ajan tärkeäksi kokemaansa asiaan. Jos hän ei olisi sitä tehnyt, emme ehkä olisi saaneet lukea hänen ajatuksiaan muutoksesta ja oppimisesta. Juuri muutoksen hitaus ja vaikeus olivat niitä asioita, jotka saivat hänet miettimään oppimisen lainalaisuuksia ja kirjoittamaan niistä The Fifth Discipline -kirjan.

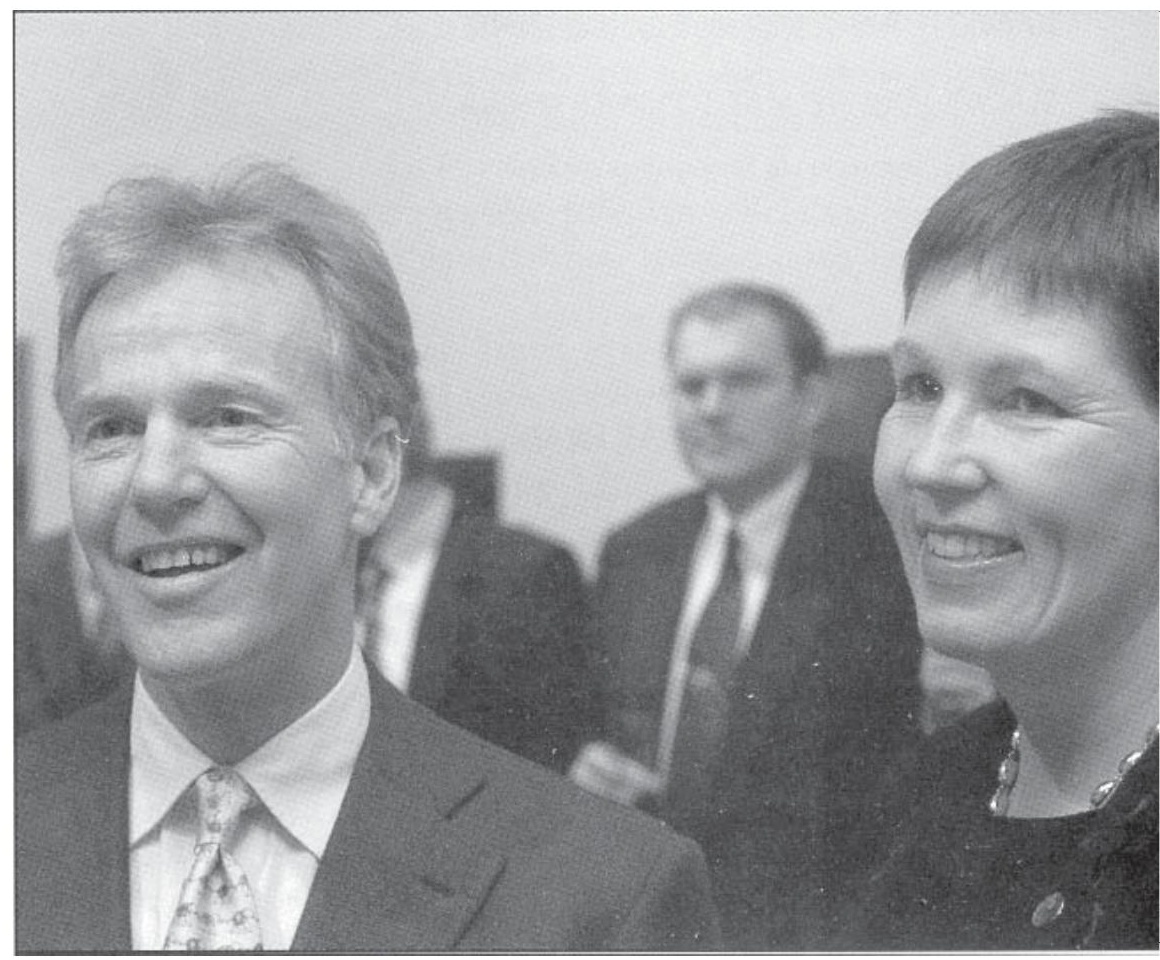
Tästä kirjasta miljoonat ihmiset ovat viime vuosikymmenen aikana päässeet ottamaan opiksi omaa työtään ja omia muutosprosessejaan varten. Kirja valittiinkin Harvard Business Review:n arvioinnissa viime vuosikymmenen merkittävimmäksi Business-kirjaksi.

Nyt hän on asialla ympäristön puolesta suoremmin ja esittää organisaation muutosmalleja kohti kestävämpää ja luonnonmukaisempaa tuotantoa.

\section{Kasvu sinänsä on luonnonmukaista}

Liikemaailman ja ympäristöarvoja puolustavien liikkeiden välinen vastakkainasettelu on Sengen mielestä aivan ymmärrettävää.

"Ympäristöliikkeiden viesti yritysmaailmalle on ollut tämä: Älkää! Pysähtykää! Kasvu seis! Se kaikki on kuitenkin liike-elämälle myrkkyä, koska niiden toiminta perustuu pyrkimykseen kasvaa. Ei kasvu sinänsä ole ympäristönvastaista. Kun auringonvalo ja energia reagoivat, seurauksena on kasvua. Oivallinen esimerkki on puu. Elämä ja luonto tuottavat kasvua. Ongelma onkin siinä, MITEN kasvamme. Kysymys on siis käsitykses-

"Koulun ajatus on ollut identtinen fordilaisen mallin kanssa. Lapsi on raakamateriaalia, jolle tarjoillaan valmiita annoksia erilaista tietoa, ja kun hän on sen riittävässä määrin omaksunut, hänet siirretään seuraavalle luokalle ja annetaan siellä taas uudet annokset tietoa. Lopussa on valmis tuote, aikuistuva ihminen. Se ei vastaa ihmisen luonnollista oppimista." Kuvassa Senge haastattelijansa, Raili Moilasen seurassa.

tämme kasvusta. Johtopäätös tästä kaikesta on se, että meidän on oltava luovia pyrkiessämme kasvuun niin, että kasvu on luonnollista”, sanoo Peter Senge ja jatkaa: "Luonto ei tuota jätettä, vaan KIERTOA. Siksi myös ihmisen aikaansaaman tuotannon tulee perustua mahdollisimman tehokkaaseen kiertoon."

\section{Paras oppiminen luonnollista ja tilannesidonnaista}

Muutos tapahtuu aina oppimisen kautta - oppiminen ja muutos kuuluvat yhteen. Siksi on tärkeää analysoida juuri oppimista. Hän puhuu luonnollisesta oppimisesta ja luonnosta meissä. Oppivassa organisaatiossa hän korostaa yksilön roolia: 


\section{A A I L M A L T A}

KAAVIO 1: Miksi teollisuus tuottaa jätettä ELÄVÄT JÄRJESTELMÄT TOIMIVAT KEHINÄ:

EL.ÄVÄT

JÄRJESTELMÄT

\section{Uusiokäyttö}

Hajoaminen

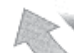

TEOLLISEN AJAN JÄRJETELMÄT EIVÄT:

Ravinteet

Hävik-

[Ex-

trac-

tion]
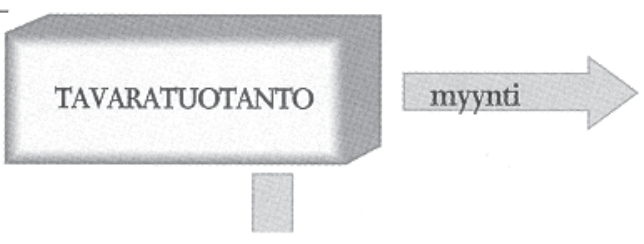

Tuotannosta syntyvä jäte

Käytöstä syntyvä jäte

TAVAROIDEN

KÄYTTÖ
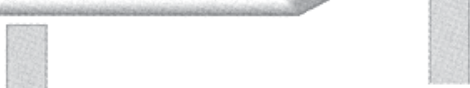

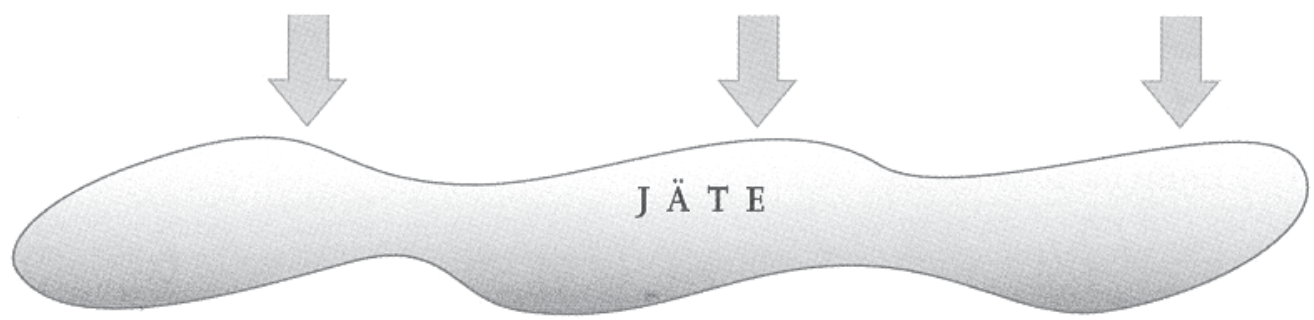

KAAVIO 2: Kuinka teollisuus voi vähentää jätteiden syntymistä: teollisen järjestelmän kierto, joka jäljittelee luontoa

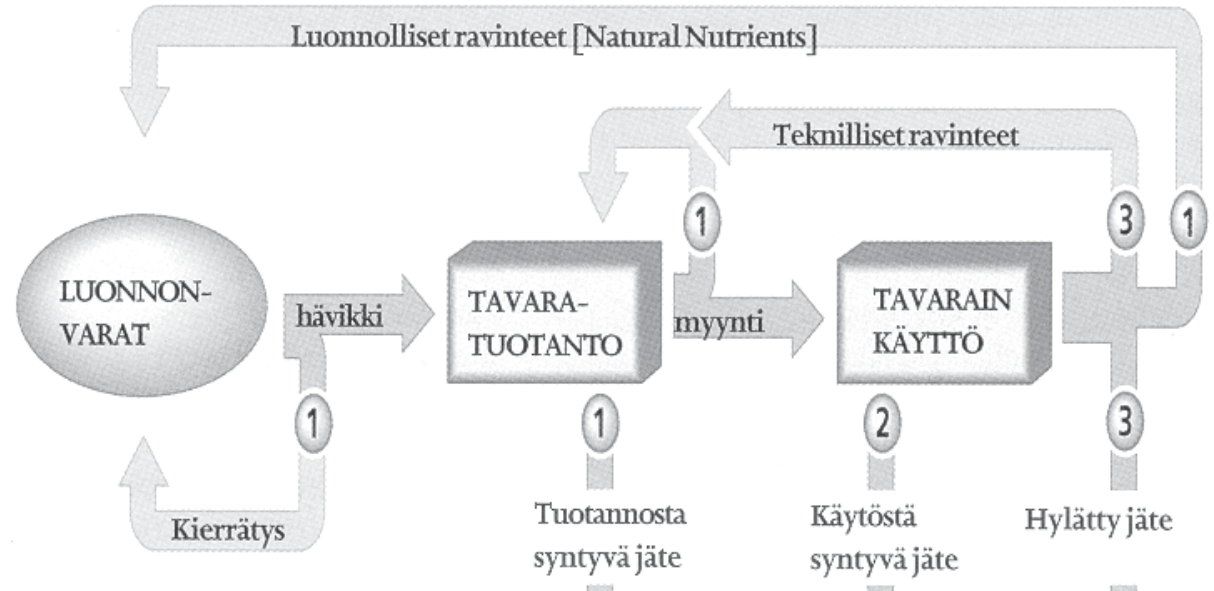

(1) TUOTTAVUUS [Resource Productivity]

(2) Puhtaat tuotteet $\mathrm{J} \ddot{\mathrm{A}} \mathrm{T}$ E

(3) Uustuotanto, kierrätys, kompostointi

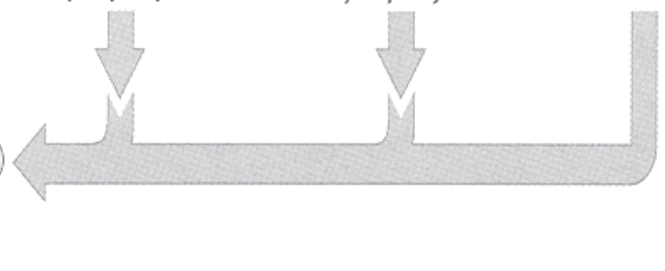


"Yksilö ohjaa omaa oppimistaan; jos joku pyytää sinua oppimaan - ei ole kovin todennäköistä, että opit kovin hyvin. Mutta jos tahdot itse oppia - se on paljon todennäköisempää! Kaikkein merkittävintä on ihmisen oma kokemus oppimisestaan", Senge totesi.

Oppiminen on tilannesidonnaista. "Kukaan ei opi hiihtämään istumalla kotona olohuoneessa, vaan ulkona hiihtoladulla. Todelliset oppimiskokemukset ihminen myös tunnistaa itse. Niissä tilanteissa hän ei siis tarvitse ulkopuolista auktoriteettia, esimerkiksi lapsi opettajaa, kertomaan, että nyt hän oppi”, Senge muistutti ja otti toisen esimerkin lapsia kiehtovista videopeleistä: "Olen pohtinut, miksi videopeleillä on lapsiin niin valtava vetovoima. Videopelithän ovat itse asiassa lähellä ihmisen luonnollista oppimisprosessia. Siinä pelaava lapsi itse tietää oman edistymisensä, eikä hän tarvitse aikuista kertomaan olkapään takaa, että nyt voit siirtyä seuraavalle tasolle. Oletteko panneet merkille, mikä on hyvin yleinen käsky lasten videopeleissä pelin edetessä? Se on: 'Kill the Boss!' Kill the boss, jotta oppiminen voi edetä! Sangen mielenkiintoista."

“Työssä tarvittavia taitoja opetellaan työssä. Samoin lapset oppivat luonnostaan tekemällä asioita yhdessä aikuisten kanssa", Senge tiivisti ja jatkoi: "Meidän on kannettava vastuu luonnosta. Mutta luonto ei ole vain se, mikä näkyy ikkunasta ulos ja minne mennään ulkoilemaan. Luonto on myös meissä, me olemme luonto. Paras oppiminen on luonnollista oppimista."

\section{Viisi periaatetta käytännössä}

The Fifth Discipline -teoksen yksi viidestä periaatteesta on systeemiajattelu. Sitäkään ei pitäisi opettaa koulutusohjelmassa, vaan, jos yksilöt ovat riittävän rationaalisia nähdäkseen monimutkaisia asioita, jonkun pitäisi auttaa heitä näkemään ne.

Systeemiajattelu nousi Sengen kongressiesityksessä keskeiselle sijalle hyvin mielenkiintoisen ja samalla erittäin konkreettisen sekä kaikkia osallistujia koskettavan aiheen kautta. Senge käytti lähes puolet esitysajastaan siihen, kuinka eri maiden koulujärjestelmät vaikuttavat yksilöiden kykyyn nähdä asiat kokonaisvaltaisina systeemeinä. Hänen mukaansa koulujärjestelmä pilkkoo elävän elämän tapahtumat ja prosessit pieniksi eriytyneiksi palasiksi, jolloin yksilöiden kyky hahmottaa laajoja kokonaisuuksia heikkenee.

Pienet lapset ovat Sengen mielestä kuitenkin hyviä systeemiajattelijoita, mutta kun he menevät kouluun, he joutuvat soveltamaan hyvin erilaista tiedon käsitettä. Tämän johdosta lapset oppivat ns. kouluhuone-mallin oikeista ja vääristä vastauksista. "Valitettavasti oikeassa elämässä ei olekaan oikeita tai vääriä vastauksia, on vain tehokkuus."

Systeemiajattelun tärkeys korostuu Sengen mukaan myös työyhteisöissä, joissa yksilöt eivät enää tyydykään tekemään pelkästään omaa työtään. He haluavat tietää yrityksen toiminnasta ja omasta roolistaan kokonaisuuden osana entistä enemmän. Tämä asettaa lisääntyviä paineita sekä johdon että esimiesten omalle kokonaisuuden hahmottamiselle ja viestintätaidoille eli kuten Senge totesi: "Johdon on opittava käsitteellistämään monimutkaista maailmaa ja tekemään nämä monimutkaiset asiat merkityksellisiksi myös muille.”

\section{Ajattelumallien tunnistaminen tienä niiden muuttamiseen}

Keskeisen periaatteen, yksilön pätevyyden ohella Senge kiinnittää huomiota ajattelumalleihin. Ajattelumallien havaitseminen, testaaminen ja muuttaminen on tärkeää, koska yksilön samoin kuin koko organisaationkin oppiminen jää tapahtumatta, jos mallit pysyvät muuttumattomina.

Senge kuvasi ihmisten ajattelumalleja näin: "Ihmiset näkevät todellisuuden hyvin pieninä palasina, eivätkä he myöskään näe sitä, kuinka heidän oma toimintansa vaikuttaa muihin. Usein ihmiset kuvittelevat olevansa kohteita, eli he eivät näe olevansa osana vaikuttamassa toisten toimintaan tai toisiin yksiköihin.”

Tämän johdosta Senge toivoikin, että reflektiivisyyttä saataisiin lisättyä ihmisten toiminnassa: "Me näemme maailman sellaisena, kuin meillä 


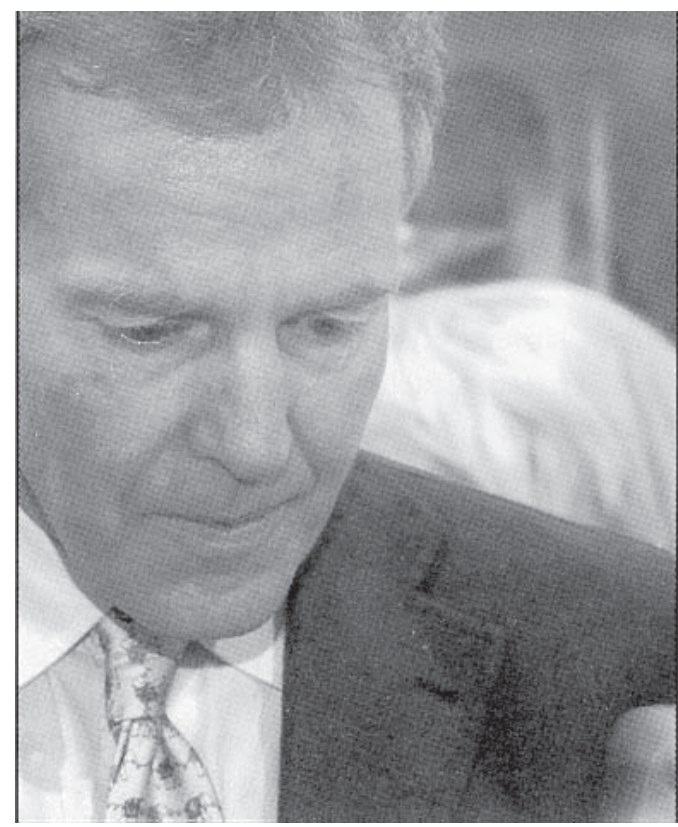

"Minua on huvittanut se, että nykypäivänä meillä on tapana puhua meistä etäämpänä olevasta historiasta 'esihistoriana', millä tarkoitetaan kuitenkin 95 prosenttia ihmislajin historiasta. Mutta ihmisten puheissa se ei ole ihmisen varsinaista historiaa, vaan jotain esihistoriaa. Kuitenkin suurimman osan olemassaolostaan lajina ihminen on elänyt heimoyhteisöissä ja siellä oppiminen tapahtui juuri tuolla luonnollisimmalla tavalla, tekemisellä yhdessä aikuisten kanssa."

on tapana kuvata sitä. Me emme todellisuudessa näekään asioita, niin kuin ne ovat. Meidän pitäisi tämän vuoksi havainnoida omaa ympäristöämme ja ajattelumallejamme paljon aktiivisemmin. Meidän pitäisi pyrkiä tulemaan enemmän tietoiseksi omista ennakkokäsityksistämme", Senge totesi.

Oppivan organisaation ydinperiaatteet, kokonaisuuden ymmärtäminen, vision rakentaminen, yksilön pätevyys, ajattelumallit ja tiimioppimisen tukeminen ovat asioita, joiden parissa riittää töitä jatkossakin. Johdon ja esimiesten on siis pystyttävä ymmärtämään kokonaisuutta ja sen kehittymistä entistä paremmin. Tämä on Sengen mukaan yksi suurimmista liikkeenjohdon haasteista tulevaisuudessa.

Ei kuitenkaan vielä riitä, että esimiehet itse tie- tävät tai osaavat edellä esitellyt asiat. Erittäin tärkeää on, että he pystyvät käymään näitä asioita läpi omassa organisaatiossaan. Tarvitaan aktiivista vuorovaikutusta, Sengen sanoin dialogia ja avoimuutta sekä erilaisuuden ymmärtämistä ja hyväksymistä. Senge totesikin, että johtajien on hyvin tärkeää kehittää kuuntelun ja puhumisen taitoja, dialogia, pystyäkseen toimimaan omassa työssään.

\section{Osuvat kysymykset muutosajattelun käynnistäjinä}

Kysyessäni haastattelun viimeisessä kysymyksessä terveisiä suomalaisille yritysten ja organisaatioiden edustajille sain mielenkiintoisen vastauksen. Senge korosti erityisesti sitä, kuinka konsultti tai kehittäjä on aina kysyjän roolissa. Yrittäjää tai yrityksen johtotehtävissä toimivaa ei voi ulkoisin keinoin motivoida kehittämään omaa organisaatiotaan. Hänet on saatava osuvilla kysymyksillä miettimään oman organisaationsa nykytilaa ja tulevaisuuden mahdollisuuksia. Vasta sitä kautta saadaan liikkeelle muutos, jolla on edes jonkinlaiset onnistumisen mahdollisuudet.

Kaiken kaikkiaan Sengen tarina on mielenkiintoinen ja kannustava, ja toivottavasti sopii myös Suomen oloihin. Kuitenkin tässä, niin kuin monessa muussakin yhteydessä on hyvä huomata, että kaikki viisaus ei asu vieraalla maalla. Esimerkiksi ympäristöön ja sosiaaliseen vastuuseen liittyvät kysymykset ovat olleet Suomessa esillä jo pitkään.

Suomalaisen koulujärjestelmän kehittyminen on ollut myös selvästi nähtävää viime vuosina. Omia koulukokemuksia ei voi enää verrata omien lasten kokemuksiin. Toivottavasti olemme menossa kohti Sengen luonnollista oppimista. Itseäni kiehtoi ja vakuutti kovasti oman toisluokkalaiseni arviointikeskustelussa esille tullut asia. Poikani epäröi viittaamista siksi, koska saattaa vastata väärin. Tähän opettaja kommentoi: Vääriä vastauksiakin tarvitaan, kuinkas me muuten saamme keskustelua aikaiseksi ja pystymme ottamaan opiksi. 


\section{Omat tulevaisuuden hasteet}

Itselleen tärkeimpinä haasteina Peter Senge näkee kestävän kehityksen jatkuvan esillä pidon ja sen mukaan toimimisen. Tämän lisäksi hän pitää erittäin suurena haasteena tulevaisuuden koulutuksen kehittämistä. Hän puhuu jopa koulutuksen ja liike-elämän vallankumouksesta tai täydellisestä uudistamisesta. "Ilman koulutuksen vallankumousta ei tule liike-elämänkään vallankumousta - niiden on autettava toinen toistaan eteenpäin”, hän totesi.

Kouluelämän ja liike-elämän linkittäminen tällä tavoin yhteen on meillä uutta. Nyt ei katsotakaan enää oppisisältöjä tai tarvittavia osaamisalueita. Senge puhuukin paljon suuremmista asioista, kun hän haluaisi nähdä oppimisen, yksilön oman persoonan ja ajattelumallien kehittymisen, ihmisten välisen vuorovaikutuksen ja systeemiajattelun asioina, joille voitaisiin luoda perusta jo lapsuudessa ja kouluaikana.

Haastattelu:RAILIMOILANEN

Valokuvat:TOMMIAALTONEN

\section{Viitteet}

Teoksen The Fifth Discipline - The Art \& Practice of the Learning Organization esitteli Aikuiskasvatus-lehdessä 4/1993 Cristina Andersson. Kirjan kustantaja on A Currency Book/ USA. Vuonna 1999 ilmestyi vähemmälle huomiolle toistaiseksi jäänyt Peter Sengen, Art Kleinerin, Charlotte Robertsin, Rick Rossin, George Rothin ja Bryan Smithin teos The Dance of Change: The Challenges of SustainingMomentuminLearning Organization. Molempien kirjojen lyhyt esittely löytyy Sengen kotisivuilta www.fieldbook. com.

2 SolConference 8.-9.11. järjestäjänä vuonna 2001 perustettu SOL Finland. Sen on määrä olla lähinnä Peter Sengen kehittämää ja hänen ajatuksiaan ja tuotantoaan markkinoivaa maailmanlaajuista verkostoa. Suomen SOL:n puheenjohtajaksi valittiin Jyväskylässä kansanedustaja Markku Markkula. Suomalainen toimipiste on Jyväskylän ammattikorkeakoulun Tiimiakatemian yhteydessä.

\section{Peter Senge ja The Fifth Discipline}

D r. Peter Senge on Senior Lecturer MIT:ssä, Massachusetts Institute of Technology. Senge opettaa, kirjoittaa ja konsultoi. Peter Sengen pääteos, The Fifth Discipline (1990), syntyi sen jälkeen, kun Senge oli vuosia tehnyt töitä fyysisen ja sosiaalisen ympäristömme muuttamiseksi. Kirja on kannanotto paremman ympäristön ja sosiaalisen tasa-arvoisuuden puolesta, vaikka kirjaa ei sellaisena ole lukijoiden keskuudessa otettukaan. Kirjasta on enemminkin tullut modernin liikkeenjohdon tuki ja oppivan organisaation kehittämisen apu. Kirjan nimen mukaisia oppivan organisaation perusperiaatteita on viisi: systeemiajattelu, yhteinen visio, yksilön pätevyys, ajattelumallit ja tiimioppiminen.

\section{Systeemiajattelu}

$\mathrm{E}$ nsimmäisenä ja kaikkein tärkeimpänä periaatteena on systeemiajattelu, joka mahdol- listaa oppivan organisaation ja sen toiminnan kokonaisvaltaisen tarkastelun. Se on tiedon ja työkalujen muodostama kokonaisuus, joka auttaa näkemään laajat ja monimutkaiset mallit tai kokonaisuudet selvemmin. Systeemiajattelu auttaa myös muuttamaan malleja tai kokonaisuutta tehokkaasti.

Systeemiajattelu on Sengen mukaan tarpeen, koska organisaatiot ovat niin laajoja ja monimutkaisia järjestelmiä, että niiden ymmärtäminen yksittäisten osien kautta on hyvin vaikeaa. Systeemiajattelussa on siis keskeistä oppia näkemään tapahtumien ja päätösten taustalla vaikuttavat toistuvat rakenteet, joita muuttamalla päästään muuttamaan myös organisaatiossa tapahtuvia prosesseja tai tapahtumia.

\section{Yhteiset visiot}

Jaetun vision rakentaminen oppivassa organisaa- 
tiossa on keskeistä. Erityisen tärkeää on se, kuinka johtajat oppivat rakentamaan yhteistä visiota ja kuinka he oppivat saamaan joukkonsa koolle luodakseen todellisia, yhteisiä merkityksiä - asia, jonka tärkeyttä Senge edelleenkin korostaa. Kuitenkin Senge pitää tärkeänä sitä, että yksilöiden omat tavoitteet ja visiot pystyisivät toteutumaan näissä yhteiseksi koetuissa visioissa. Senge luottaa yksilöiden omaan innostukseen ja visioon. Hänen mukaansa vision merkitys oppimisessa ja oppivassa organisaatiossa perustuu suurelta osin siihen, että vain henkilökohtaisesti arvokkaaksi koettu asia on riittävän merkityksellinen ja tavoittelemisen arvoinen. Myös oppiminen nousee tässä yhteydessä esille, eli yksilöt ovat sitä valmiimpia oppimaan, mitä tärkeämmästä asiasta on heidän kannaltaan kysymys.

Arvoilla on keskeinen merkitys kehittyvässä organisaatiossa. Arvot tulee ottaa mukaan yrityksen tuloskeskusteluun. Vain aidosti organisaation arvoihin samaistuva yksilö toimii automaattisesti arvojen suuntaisesti. Yksilölle arvo on arvo kuitenkin vain silloin, kun hän valitsee sen vapaaehtoisesti.

\section{Yksilön pätevyys}

Ys ksilöllä on oppivan organisaation kokonaisuuden muodostumisessa oma roolinsa ja merkityksensä, kuten jaetun vision syntymisessä. Yksilön pätevyyden kehittäminen tarkoittaa sitä, että yksilö jatkuvasti kirkastaa ja kehittää omaa henkilökohtaista visiotaan, suuntaa energiaansa, kehittää omaa kärsivällisyyttään ja kehittää kykyään nähdä todellisuus objektiivisesti. Tällä tavoin kuvattu pätevä yksilö on myös hyvä oppija, sillä hän pystyy pitämään jatkuvasti yllä oppimisen kannalta tärkeää luovaa jännitettä.

Senge korostaa myös sitä, että yksilöiden itsearviointia on syytä kehittää. Yksilöt ovat parhaita oman oppimisensa arvioijia, mutta heitä pitäisi tukea, jotta he pystyvät havainnoimaan oman ajattelunsa ja toimintansa kehittymistä.

\section{Ajattelumallit}

$\mathrm{K}^{2}$ aikki yksilöt eivät ole hyviä oppijoita ja oman penge nostakin yhdeksi oppivan organisaation perusperiaatteeksi ajattelumallit. Ajattelumallit ovat Sengen mukaan yksilön mielikuvia tai käsityksiä siitä, kuinka maailma toimii. Näiden ajattelumallien havaitseminen, testaaminen ja muuttaminen on erittäin tärkeää, koska yksilön samoin kuin koko organisaationkin oppiminen jää tapahtumatta, jos mallit pysyvät muuttumattomina.

Ajattelumallit voivat siis toimia oppimisen esteinä. Yksilöillä on erilaisia puolustusmekanismeja, joiden avulla he pyrkivät puolustautumaan uusien asioiden ja prosessien oppimiseen liittyvältä tuskalta ja epävarmuudelta. Välttääkseen muutokseen liittyviä kielteisiä vaikutuksia he jäävät samalla paitsi myös muutokseen liittyvistä positiivista asioista.

\section{Oppiminen tiimissä}

$\mathrm{V}$ iimeisenä oppivan organisaation perusperiaatteena on tiimioppiminen, joka perustuu kahdelle muulle periaatteelle eli jaetun vision ja yksilön pätevyyden periaatteelle. Tiimioppiminen on yhteydessä myös ajattelumalleihin. Tiimin oppiminen ei nimittäin onnistu, ellei erilaisia ajattelua ja kehittymistä rajoittavia ajattelumalleja pystytä tunnistamaan ja poistamaan. Kaiken kaikkiaankin Senge korostaa aktiivisuuden ja harjoittelun merkitystä tiimioppimisessa. Vain omaan työhön ja työympäristöön liittyviä asioita on syytä opetella juuri niille sopivassa ympäristössä eli omassa työssä.

Yksilöiden ajattelumalleja voidaan osin kehittää tiimioppimisen avulla. Tiimi tarjoaa mahdollisuuden tehdä asioita yhdessä ja sitä kautta oppia toisilta ryhmän jäseniltä. Tiimissä työskentely mahdollistaa myös oman ja toisten toiminnan aktiivisemman havainnoinnin ja sen kautta oppimisen. Senge korostaa tässä keskustelun ja dialogin taitoja, mutta myös kyselyyn ja yhteisen kielen harjoitteluun liittyvien taitojen kehittämistä.

\section{RAILI MOILANEN}

RAILI MOILANEN, KTT, johtamisen oppiaineiden yliassistentti, Jyväskylän yliopisto. Väitöskirja: Raili Moilanen (2001) A Learning Organization: Machine or Human? Jyväskylä Studies in Business and Economics, 14/2001. ISBN 951-39-0996-4, ISSN 1457-1986. Muita julkaisuja: Oppivan organisaation mahdollisuudet, Tammi 2001. ISBN 951-26-4851-2. 